\title{
Informal Relationships as a Predictor of Organizational Commitment in Schools of Turkey as a Collectivist Society
}

\section{Research Article}

\author{
Ahmet SAYLIK ${ }^{1}$, Hasan Basri MEMDUHOGLU² \\ ${ }^{1}$ Siirt University, Faculty of Education, Department of Social Science Education, ORCID: 0000-0001-7754-2199 \\ ${ }^{2}$ Siirt University, Faculty of Education, Department of Educational Sciences, ORCID: 0000-0001-5592-2166
}

To cite this article: Saylik, A., \& Memduhoglu, H. B. (2021). Informal relationships as a predictor of organizational commitment in schools of Turkey as a collectivist society, International Online Journal of Educational Sciences, 13(4), 1218-1234.

\begin{tabular}{|c|c|}
\hline ARTICLE INFO & ABSTRACT \\
\hline Article History: & $\begin{array}{l}\text { In schools, as formal organizations, formal relationships defined by formal rules for employees exist, } \\
\text { and informal relationships (natural, intimate) as a form of social relations are experienced as well. }\end{array}$ \\
\hline Received: 22.03 .2021 & $\begin{array}{l}\text { Intimate, face-to-face, and natural relations experienced at a national level are reflected in the } \\
\text { organizational relationships in Turkey, where a collectivist culture structure is dominant. With their }\end{array}$ \\
\hline Available online: & loose structure, schools are among the organizations in which such relationships are experienced \\
\hline 14.07.2021 & intensely. It is expected that natural, informal relationships between school employees will increase \\
\hline & teachers' organizational commitment. The purpose of the research, for which the survey method is \\
\hline & employed, is to explore informal relationships in primary schools and organizational commitment \\
\hline & levels of school employees in administrators' and teachers' views and to determine whether they are \\
\hline & correlational. The sample of the study consists of 465 administrators and teachers who work primary \\
\hline & schools in Diyarbakır provincial and district centers. The research concludes that Schools have \\
\hline & moderate and positive informal relationships. Informal relationships are not advanced outside of \\
\hline & school and employees do not establish personal communication outside of work. There is a moderate \\
\hline & level of organizational commitment in schools. Employees' commitment to the organization they \\
\hline & work for is higher in terms of the adaptability dimension in which more importance is given to \\
\hline & financial benefits and obligations rather than identification or internalization. The research concludes \\
\hline & that there is a positive, moderate correlation between informal relationships and organizational \\
\hline & commitment levels of school employees and intra-and-extra organizational informal relationships \\
\hline & among teachers significantly predict their school commitment. \\
\hline
\end{tabular}

Keywords:

informal relationships, organizational commitment, school, collectivist society 


\section{Introduction}

Communication is the main factor underlying all social interactions. If man is deprived of socializing effect of communication, it means he is merely a biological entity (Bilgiç, 2006). Organizations in modern societies are mostly shaped by formal relationship network as they are managed through bureaucratic understanding. However, human beings, as psycho-social creatures, cannot do only with inflexible, predefined formal relationships, but also build informal ones in time (Y1lmaz, 2007). The Hawthorne studies, conducted by Mayo and et.al, observed that employees formed informal groups and developed friendships. Those studies showed some psycho-social motives in individual motivation such as communication, involvement in decision making and human relations were more influential than economic ones; thus, natural (informal) groups were more influential than formal groups in organizational goal attainment (Sabuncuoğlu, 1984; Varol, 1993: 29).

While playing their social roles, man, as a social being, may develop a multidimensional, complicated relations network with those who have different status and roles in society (Eserpek, 1981; Türkkahraman, 2009). Groups formed by individuals in interaction are quite diverse. The theory of Charles Cooley (1909/1962), which distinguishes groups as primary and secondary based on the forms of interpersonal social relationships, is of significance in the literature of sociology. However, Ferdinand Tönnies (1877/1957) made a distinction between social groups and members in the context of the character of the relationships with Gemeinschaft (community) and Gemeinschaft (society), while Emile Durkheim (1893/1960) did so with the typology of "mechanical-organic solidarity". In these approaches, primary groups, community, and social structures with mechanical solidarity are quite similar in terms of cultural characteristics. Likewise, the classifications of secondary groups, community, and organic solidarity are very similar. The characteristics of social groups and dominant human relations are given in a comparative manner in Table 1.

Table 1. Comparison of characteristics of social groups

\begin{tabular}{ll}
\hline Informal-Community Type-Primary Groups & Formal-Society Type-Secondary Groups \\
\hline Affective, intimate, face-to-face & Pragmatic, hierarchical \\
Personalities-real & Status quoist-Corporate \\
Spontaneous-affective behaviors & Behaviors by rules \\
Life-sustaining, natural togetherness & Goal oriented (Role-Status) togetherness \\
Overwhelming We-feeling & Overwhelming I-feeling \\
Oral communication & Generally written communication \\
Family, friendship, citizenship, neighborhood & Governmental Agency \\
Converging interests & Conflicting interests \\
Abstentious individual & Competitive and ambitious individual \\
Agriculture-based economy & Industry-science-and-technology-based economy \\
Limited social change & Rapid social change \\
Voluntary relationships & Contractual relationships \\
Ascribed social status & Achieved specialization-required status \\
Religions, customs, and traditions & Written norms such as laws and contracts \\
\hline
\end{tabular}

As it is clear from the table 1, primary, intimate, natural informal relationships are seen in community type social groups, whereas hierarchical, status quoist and goal oriented relationships are highlighted in society type formal structures where secondary relationships are dominant. In informal (natural) groups, with a strong feeling of solidarity, sympathy, antipathy, love and hate are simultaneously felt (Aslan, 1997, 81-84; Eren, 1989, 91; Fichter, 2004: 71; Tezcan,1995: 63). Such informal or natural relationships which are spontaneously developed between employees who spend most of the day in the workplace, beyond hierarchical order defined by formal rules are a social reality (Sabuncuoğlu, 1984). However, the form and intensity of informal relationships varies from culture to culture. 
In his book titled “Culture's consequences: National differences in thinking and organizing" published in 1980, Hofstede proposed six dimensions that reveal cultural differences by separating societies into cultural clusters. Among these dimensions, the dimension of individualism/collectivism is the most discussed cultural differentiation dimension in theoretical and empirical organizational studies (Hofstede, 1980).

The majority of the world population consists of people who prefer group relations to individual relationships. Children growing up in such societies defined as collectivists involuntarily become a part of the web of relationships in which they are at the center of the understanding of "we". Group loyalty is very important. Thus, a mutually dependent relationship develops between the individual and the group both in daily life and psychologically (Hofstede et al., 2010, 90-91). A minority of the world population are individualist societies that prefer the interests of the individual to the interests of the community. In such societies, children are born into a family structure with parents and possibly children. Relations with relatives are rather shallow and weak. In individuals raised in families defined as nuclei in terms of their structure, the consciousness of "I" forms the personality character and identities. To be a healthy individual in this type of society, there is no need for any group consciousness that requires psychological or physical support (Hofstede, 2001, 227; Hofstede et al., 2010, 91). In such individualistic societies, both business relations and relationships in social life are at a distant level with certain norms to protect the private sphere. However, close relatives, fellow citizenship and friendly relations that prevail in collectivist societies are also reflected in business life, which is structurally formal, and can overshadow the essential formal communication when it is not controlled administratively.

Turkey is a Eurasian country undergoing a process of social change between modern and secular targets with its multicultural social structure and agricultural-religious tradition. Particularly during the last quarter of the century, the rapid development and integration into the global impact on science and technology, and notably on economy, seem to have accelerated the cultural change in Turkey in a highly versatile and surprising way (Saylik, 2017). Depending on this rapid change, Turkey owns a collectivist structure which is culturally evolving into individualism.

According to Hofstede (1980b) study, Turkey is ranked among the group of the Middle East, Latin American, African, and Asian countries with 37 points taken in individualism scale, revealing a relatively collectivist cultural structure (Hofstede, 1984b). In this respect, Turkey is a country that highlights the close interpersonal relationships (İmamoğlu, 1987; Kağıtçıbaşı, 1984) and where culture of acting together is relatively more dominant (Sargut, 2015, 185). Therefore, even in organizations which are distinct with their formal structure, family, friend groups, relatives, and fellow citizenship, and unionism relationships become evident, albeit in informal ways (Saylık, 2017; Saylık, 2020). Therefore, the relationship and communication styles at the social level are also reflected in formal organizations.

In both individualist and collectivist societies, informal relationships emerge in almost every formal organization, albeit at different intensities, and with positive and negative effects on the atmosphere of the organization.

\section{Formal Relationships}

The form and limits of formal relationships that emerge in official institutions can be defined as relationships that are far from personality and emotionality and determined by formal rules, regulations, and laws. Hierarchy is inevitable in bureaucratic structures. In such a corporate structure, it is expected that the operation will be processed professionally, away from individuality and emotionality or the personalities and world views of the employees. In such professionalism, the position or status of the people is essential (Yilmaz, 2007: 31). Bureaucratic hierarchy determines the boundaries of the relationship and communication between employees. Written communication takes priority. The protocol rules, which are official etiquette with such 
institutions, draw the boundaries of the forms and behaviors that managers and all employees have to obey and apply. But in bureaucratic organizations, the formal structure does not mean everything. In practice, the informal structure formed by the attitudes, behaviors, understandings, and traditions that employees develop among themselves can substitute for or turn into a form that complements the formal structure, especially in collectivist societies.

\section{Informal Relationships}

This type of relationship, which is determined by factors including common habits, beliefs, thoughts, emotions, value structures, traditions and customs, race, gender, age, language, religion, professional affiliations, entertainment, sports, special days, and citizenship which, apart from the written and formal rules, often affect the individual and direct the behavior of the resources that are developed among themselves, is generally established face-to-face (Sabuncuoğlu, 1984: 32). Relationships that occur in informal groups, also called primary groups, cause strong emotional reactions. While it typically occurs in the form of love, affection, and friendship, it can sometimes appear in the form of hate. Individuals who can develop informal relationships gain information about the whole of each other's personalities and the relationships that develop with everyone else become personal (Dönmezer, 1982: 207).

\section{Advantages and Disadvantages of Formal and Informal Relationships}

According to Lundberg, Schrag \& Larsen, (1970: 113), it should not be accepted in advance that primary relationships have detrimental effects on social or institutional structures. For, the primary groups, which are the miniature of society, serve to ensure the sociality of the individual. If this situation is evaluated correctly, it can be beneficial for secondary structures. The primary relationships provided by the primary groups can also provide a supportive power to secondary structures, which are formal organizations, by revealing feelings of unity and togetherness and sympathy. 'If a special relationship such as friendship, kinship, affection, or other in-group emotion prevails in the group, members of that group are more likely to cooperate if they do not know or love each other. For example, a working group whose members are friends outside of work will probably cooperate at work "(Cited in: Y1lmaz, 2007).

Informal relationships provide additional communication channels for the formal organization. Studies show that gossip and rumor, which are thought to be destructive in the traditional management approach, disseminate more news than the formal communication network. Another positive function of informal relationships and communication is the direct or indirect involvement of stakeholders and collective decisions, which can play an important role in building a sense of belonging and trust.

Groups dominated by informal relationships can sometimes harm the formal organization in which they emerge. Informal relationships can turn into clicks, and clicks can turn into discipline problems. Similarly, if relationships based on elements such as regionalism, fellowship, and unionism are kept at an excessive level in the institution, it can create a negative situation by preventing the basic goals of the institution (Dönmezer, 1982: 209-210). In collectivist Eastern societies, the intensity of informal relationships can override the formal structure. This can turn into a problem that needs attention in management processes.

Informal relationships increase the flow and transfer of emotions between group members, so that love, understanding, unity, integrity, and solidarity can dominate the organization. This situation partially provides the group members with an environment to act freely, and thanks to these relations, they have the opportunity to alleviate the pressure of the rigid bureaucratic structure of the organization (Yllmaz, 2007).

Since individuals are the input and output of educational organizations, communication, type and quality of human relations are much more important in these organizations than others (Bolat, 1996). Various studies showed that there was a correlation between type and quality of relationships between employees in 
educational organizations and their motivation, performance, job satisfaction and organizational commitment (Bolat, 1996; Celep, 1992; Çubukçu \& Dündar, 2003; Özan, 2006).

\section{Organizational Commitment}

Allen \& Meyer (1990) stated that organizational commitment is a psychological approach that reflects the relationship between the employee and the organization, serving the decision to continue membership in the organization. Organizational commitment means people's beliefs in job participation, loyalty and organizational values as well as their psychological ties with organizations (Çetin, 2004: 90). Those who are adaptable to their organizations in terms of attitudes and behaviors and have soundly built primary relationships with coworkers, thus a strong feeling of job satisfaction, are expected to be loyal to organizations. One of the main goals of organizations is to increase organizational commitment of employees. According to research, employees with high organizational commitment show greater performance and participation in organizations and organizational goals than those who lack commitment. They also build more intimate, better relationships with others, so have higher job satisfaction levels (Budak, 2009). Accordingly, commitment to colleagues is an important factor that fosters organizational commitment.

Commitment to colleagues refers to the identification of the individual with and loyalty to other employees. It can be a tool and sometimes a purpose in the direction of interests that break commitment to friends. A study conducted on this issue reveals that the employees prefer to communicate with their own group members rather than with others. Commitment to colleagues helps to overcome any related assets. With this awareness, employees get closer to each other, contributing to the emergence and development of the sense of solidarity. For these reasons, it is suggested that commitment to friends will lead individuals to a stronger professional and organizational commitment (Balay, 2000).

In schools, as formal organizations, formal relationships defined by formal rules for employees exist, and informal relationships (natural, intimate) as a form of social relations are experienced as well. Both intimate, informal relationships between employees in schools and out-of-job social sharing strengthen feelings of collaboration and solidarity and team spirit. As a result, they are expected to increase performance, job satisfaction and school organizational commitment. The research examines the correlation between informal relationships between school employees and their organizational commitment.

\section{Research Goal}

The aim of this study is to explore informal relationships in primary schools and organizational commitment levels of school employees in administrators' and teachers' views. The study also examined whether there was a correlation between intra and extra organizational informal relationships and organizational commitment of employees. The questions of the research are as follows:

1. To what extent the level of informal relations in schools?

2. To what extent the level of organizational commitment in schools?

3. Do the opinions of administrators and teachers on informal relationships and organizational commitment in schools differ significantly according to seniority, title and school size (total number of teachers and total number of students)?

4. Is there a relationship between intra-school and extra-school informal relationships in primary schools and organizational commitment according to the opinions of administrators and teachers?

5. Do informal relationships at schools predict teachers' organizational commitment?

\section{Method}


This part of the study includes the purpose, model, sample, information about the participants, data collection tools used in the research, and data analysis techniques adopted in the research.

\section{Research Model}

This research is a descriptive study in which "causal-comparative research" and "correlational research" designs are used together. Correlational research was used to describe the relationship between two or more variables within the conditions of the researched subject (Fraenkel \& Wallen, 2003). Accordingly, the informal relationship level and organizational commitment levels among teachers working in public primary schools were described and the relationship between them was examined. In the causal-comparative research design, on the other hand, the relationships between the variables are investigated and estimations are made regarding possible causes through intergroup comparisons (Balc1, 2013, p. 260).

\section{Sample and Data Collection}

The population of the research, for which the survey method was employed, consisted of primary school administrators and teachers in Diyarbakır province which located south of Turkey. The sample of the study consisted of 465 primary school administrators and teachers in the chosen seven districts, four of which were central (Kayapınar, Sur, Yenişehir, Bağlar, Bismil, Çınar, Kocaköy). Socio-economic development level was the main criterion to choose from the districts off the center. Stratified sampling, one of the random sampling methods, was taken as the basis for sampling. Stratified sampling is a sampling method that aims to determine the subgroups in the population and to sample them with their ratios in the population size. In this method, the population is divided into substrata and a sample is selected from each stratum in proportion to its weight (Büyüköztürk, 2010, 85). The ratio of the number of teachers working in the seven district units included in the sample to the total number of teachers was found and the number of teachers in the schools where the research would be conducted was determined according to these ratios. Teacher selection was made in a random way.

The percentage and frequency information regarding the distribution of teachers participating in the study according to independent variables (title, seniority, number of teachers, number of students) are given in Table 2.

Table 2. Personal information regarding the sample group

\begin{tabular}{llcc}
\hline \multicolumn{1}{c}{ Variable } & Level & $\mathbf{n}$ & $\mathbf{\%}$ \\
\hline \multirow{2}{*}{ Title } & Administrator & 76 & 16.3 \\
& Teacher & 389 & 83.7 \\
\hline \multirow{4}{*}{ Seniority } & $1-5$ years & 121 & 26.0 \\
& $6-10$ & 126 & 27.1 \\
& $11-15$ & 106 & 22.8 \\
& 16 and over & 112 & 24.1 \\
\hline \multirow{4}{*}{ Number of Teachers } & 30 and under & 102 & 21.9 \\
& $31-60$ & 145 & 31.2 \\
& $61-90$ & 179 & 38.5 \\
& 91 and over & 39 & 8.4 \\
\hline \multirow{4}{*}{ Number of Students } & 900 and under & 105 & 22.6 \\
& $901-1800$ & 181 & 38.9 \\
& $1801-2700$ & 141 & 30.3 \\
& 2701 and over & 38 & 8.2 \\
\hline
\end{tabular}


The data in Table 2 reveal that 389 of the sample group are teachers and 76 are administrators. The distribution of the participants in the seniority groups is close to each other. Half of the participants work in small schools with less than 60 teachers in terms of school size and half of them work in large schools with more than 60 teachers.

\section{Research instrument}

The data gathering instrument incorporated the Organizational Commitment Scale, developed by Balay (2000) and the Informal Relations Scale at Schools, developed by the authors (Memduhoğlu \& Saylik, 2012). Item total correlations of the Organizational Commitment Scale, consisting of three factors (adaptability-8 items, identification-8 items and internalization-11 items), were ranging from .38 to .68 for the first factor, from .33 to .75 for the second, and from .53 to .83 for the third. The Cronbach Alpha value was found as .79 for the first factor, .89 for the second, and .93 for the third. The reliability coefficients obtained in this study were calculated as .80 for conformity, .89 for identification, .91 for internalization, and .91 for the composite scale. High scale scores represented high organizational commitment, while low scale scores represented low organizational commitment.

The Informal Relations Scale consisted of two factors; intra (10 items) and extra (7 items) organizational informal relationships. Some sample items for intra schools dimension are as follows: "There are friendly and warm relations between colleagues", "Employees are seen as members of the family". Some sample items for extra schools dimension are as follows: "employees arrange home visits to each other", "employees attend each other's special days (marriage, engagement, condolence, sick visit, etc.)". Item factor loadings were ranging from .52 to .83 . Item total correlations were ranging from .48 to .68 for the first factor, and from .49 to .58 for the second. The proportion of variance explained by the first factor was found $41.09 \%$ and the proportion of variance explained by the second factor was found $14,36 \%$. The total variance explained by the both factors was $55.46 \%$. The Cronbach Alpha value was found .94 for the first factor, .86 for the second, and .90 for composite scale. The Cronbach alpha values obtained in this study were calculated as .90 for informal relations within the organization, as .86 for informal relations outside the organization, and as .91 for the overall scale. The high score on the scale shows that there is a high level of sincere and natural relations among employees in schools (Memduhoğlu \& Saylık, 2012). Both were five-point Likert type scales.

\section{Analyzing of Data}

A number of criteria were considered in deciding which of the parametric or non-parametric test methods to use in the analysis of the data. The fact that the research sample is 50 or more is the first factor that enables the use of parametric test methods (Kilmen, 2015). According to Randolph and Myers (2013, 49), one of the elements that show the normality of a distribution is skewness and kurtosis statistics. As a result of the analyzes made in this study, whose sample consisted of $465(\mathrm{~N}>50)$ people, the mean, median, and mode values were generally close to each other in all dimensions; the points were gathered close to the 45-degree line on the Q-Q graph, and; the skewness coefficients ranged between -1.5 and +1.5 . When the Levene test results were examined according to the independent variables for the homogeneity of the data, it was seen that the $\mathrm{p}$ value was greater than .05 in all dimensions along with compared groups such as male and female ( $p>$.05). In the light of all these results, the researcher decided to use parametric test methods in the analysis of the research data.

Descriptive statistics (percentage, frequency, arithmetic mean, standard deviation) were used for data analysis, the t-test and ANOVA were used for difference analyses, and correlation and multiple regression analysis were used to determine the correlation between informal relationships and organizational commitment. 


\section{Findings}

In this section, the findings obtained as a result of the analysis of the data collected from teachers with data collection tools via the descriptive and inferential statistical techniques and analyzes described in the method section, are tabulated and interpreted in accordance with the purpose and sub-objectives of the study.

\section{Findings regarding the level of informal relationships in schools}

Arithmetic means and standard deviation values of the participants' views about the Informal Relations Scale factors, grand and total averages were listed in Table 3.

Table 3. Arithmetic mean values of informal relationship views according to factors

\begin{tabular}{lcc}
\hline \multicolumn{1}{c}{ Factors } & $\bar{X}$ & sd \\
\hline Intra-school & $3.07 / 30.7$ & 8.25 \\
Extra-school & $2.53 / 17.7$ & 5.66 \\
\hline Composite scale average & $2.85 / 48.5$ & 12.05 \\
\hline
\end{tabular}

As it is clear from Table 3, the participants thought moderate $(\bar{X}=3,07)$ intra organizational informal relationships existed between staff in their primary schools, while extra organizational informal relationships were below moderate level ( $\bar{X}=2,53$ ). Accordingly, it can be argued that teachers and administrators have natural and sincere relations within the school. On the other hand, it can be said that the employees in schools have limited contact outside working hours.

\section{Findings regarding the level of organizational commitment in schools}

Arithmetic means and standard deviation values of the participants' views about the Organizational Commitment Scale factors, grand and total averages were listed in Table 4.

Table 4. Arithmetic mean values of organizational commitment views according to factors

\begin{tabular}{ccc}
\hline Factors & $\bar{X}$ & sd \\
\hline Adaptability & $3.92 / 31.43$ & 6.54 \\
Identification & $2.70 / 21.61$ & 7.63 \\
Internalization & $3.38 / 37.27$ & 9.22 \\
\hline Composite scale average & $3.34 / 90.31$ & 17.90 \\
\hline
\end{tabular}

As it is clear from Table 4, the participant primary school administrators and teachers stated that they had "moderate" ( $\bar{X}=3.34$ ) organizational commitment levels according to the grand scale average. When factor means are considered, it is obvious that the participants were "largely" ( $\bar{X}=3.92)$ adaptable to their organizations, but "moderately" ( $\bar{X}=2.70$ ) identified themselves with their organizations and internalized their organizations $(\bar{X}=3.34)$.

\section{Findings Regarding Personal Variables}

The findings obtained from the t-test to determine whether the participants' opinions on their informal relationships and organizational commitment differ according to the title variable were given in Table 5.

Table 5. T-test results according to title variables

\begin{tabular}{|c|c|c|c|c|c|c|c|c|}
\hline & Variable & Level & $\mathbf{n}$ & $\bar{X}$ & ss & Sd & $\mathbf{T}$ & p \\
\hline \multirow{3}{*}{ 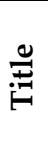 } & Informal & Administrator & 76 & 52.02 & 8.93 & \multirow{2}{*}{462} & \multirow{2}{*}{3.469} & \multirow{2}{*}{.001} \\
\hline & Relationships & Teacher & 388 & 47.84 & 12.47 & & & \\
\hline & & Administrator & 76 & 93.94 & 15.35 & 463 & 1.939 & .053 \\
\hline
\end{tabular}


Organizational

$\begin{array}{lllll}\text { Commitment } & \text { Teacher } & 388 & 89.6 & 18.28\end{array}$

The table 5 reveals that there is a significant difference between the title and informal relationships [ $\mathrm{t}$ $(139)=3,469 ; \mathrm{p}<.05]$. Accordingly, administrators have higher perception about informal relationship at school they work when compared to teachers. There is no significant relationship between the title and organizational commitment. The findings of the ANOVA test conducted to determine whether the opinions of teachers on informal relationships and organizational commitment differ according to the variables of their seniority and the number of teachers and students in their schools were given in Table 6.

Table 6. ANOVA test results according to the variables of seniority, number of teachers and number of students

\begin{tabular}{|c|c|c|c|c|c|c|c|c|c|c|c|}
\hline \multicolumn{2}{|c|}{ Variable } & Level & $\mathbf{n}$ & $\bar{X}$ & ss & $\begin{array}{l}\text { Sum of } \\
\text { squares }\end{array}$ & sd & $\begin{array}{l}\text { Mean } \\
\text { square }\end{array}$ & $\mathbf{F}$ & $\mathbf{P}$ & $\begin{array}{c}\text { Difference } \\
\text { (Scheffe) }\end{array}$ \\
\hline \multirow{8}{*}{ 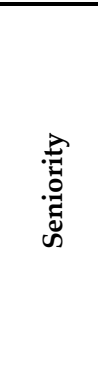 } & \multirow{4}{*}{$\begin{array}{c}\text { Informal } \\
\text { Relationships }\end{array}$} & $1-5$ years & 121 & 48.75 & 12.71 & 461.19 & 3 & 153.73 & 1.058 & .367 & \\
\hline & & $6-10$ & 126 & 48.642 & 12.02 & 66844.325 & 460 & 145.314 & & & \\
\hline & & $11-15$ & 106 & 46.877 & 12.31 & 67305.515 & 463 & & & & \\
\hline & & 16 and over & 112 & 49.741 & 11.20 & & & & & & \\
\hline & \multirow{4}{*}{$\begin{array}{l}\text { Organizational } \\
\text { commitment }\end{array}$} & $1-5$ years & 121 & 86.388 & 17.44 & 6593.333 & 3 & 2197.778 & 7.135 & .000 & $4-1,4-2$ \\
\hline & & $6-10$ & 126 & 89.833 & 18.71 & 142007.6 & 461 & 308.042 & & & $4-3$ \\
\hline & & $11-15$ & 106 & 88.735 & 16.27 & 148600.9 & 464 & & & & \\
\hline & & 16 and over & 112 & 96.607 & 17.50 & & & & & & \\
\hline \multirow{8}{*}{ 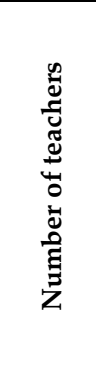 } & \multirow{4}{*}{$\begin{array}{c}\text { Informal } \\
\text { Relationships }\end{array}$} & 30 and under & 102 & 52.607 & 14.16 & 2278.071 & 3 & 759.357 & 5,372 & .001 & $1-2,1-3$ \\
\hline & & $31-60$ & 145 & 47.924 & 10.24 & 65027.444 & 460 & 141.364 & & & $1-4$ \\
\hline & & $61-90$ & 179 & 47.213 & 11.53 & 67305.515 & 463 & & & & \\
\hline & & 91 and over & 39 & 46.153 & 12.70 & & & & & & \\
\hline & \multirow{4}{*}{$\begin{array}{l}\text { Organizational } \\
\text { commitment }\end{array}$} & 30 and under & 102 & 93.352 & 16.42 & 1452.661 & 3 & 484.22 & 1,517 & .209 & \\
\hline & & $31-60$ & 145 & 88.689 & 18.41 & 147148.2 & 461 & 319.194 & & & \\
\hline & & $61-90$ & 179 & 89.659 & 18.87 & 148600.9 & 464 & & & & \\
\hline & & 91 and over & 39 & 91.461 & 14.24 & & & & & & \\
\hline \multirow{8}{*}{ 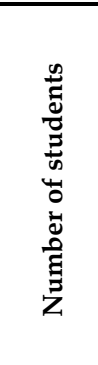 } & \multirow{4}{*}{$\begin{array}{c}\text { Informal } \\
\text { Relationships }\end{array}$} & 900 and under & 105 & 53.209 & 13.89 & 3059.284 & 3 & 1019.761 & 7,301 & .000 & $1-2,1-3$ \\
\hline & & $901-1800$ & 181 & 47.375 & 10.71 & 64246.231 & 460 & 139.666 & & & $1-4$ \\
\hline & & $1801-2700$ & 141 & 47.285 & 11.29 & 67305.515 & 463 & & & & \\
\hline & & 2701 and over & 38 & 45.71 & 12.56 & & & & & & \\
\hline & \multirow{4}{*}{$\begin{array}{c}\text { Organizational } \\
\text { commitment }\end{array}$} & 900 and under & 105 & 92.952 & 17.13 & 1266.446 & 3 & 422.149 & 1,321 & .267 & \\
\hline & & $901-1800$ & 181 & 88.685 & 17.65 & 147334.4 & 461 & 319.598 & & & \\
\hline & & $1801-2700$ & 141 & 90.141 & 19.47 & 148600.9 & 464 & & & & \\
\hline & & 2701 and over & 38 & 91.473 & 14.43 & & & & & & \\
\hline
\end{tabular}

The organizational commitment levels of the participants differ according to their seniority $[\mathrm{F}(3-460)=$ 5,372; $\mathrm{p}<.05]$. Accordingly, administrators and teachers who have seniority of 16 years or more have a higher sense of organizational commitment than administrators and teachers have less than 16 years seniority. The opinions of the administrators and teachers participating in the study on informal relationships in schools change depending on the seniority. Likewise, the organizational commitment levels do not differ according to the total number of teachers and students in their schools.

As seen in Table 6, participants' opinions on informal relationships differ according to the number of teachers $[F(3-460)=5,372 ; p<.05]$ and the number of students $[F(3-460)=7.301 ; p<.05]$ that shows the school size. Accordingly, informal relationships in schools with 30 or less teachers are at a higher level than in all other schools with a higher number of teachers. A similar result emerges when the number of students in schools is taken into account, considering the assumption that there is an average of 30 students per teacher. Informal relationships in schools with a student number of 900 and below are at a higher level than in all other 
school groups with a higher number of students. On the other hand, the opinions on the organizational commitment do not differ according to the number of teachers [F (3-460) $=5,372 ; p>.05]$ and students $[F$ (3$460)=5,372 ; p>.05]$ that shows the school size.

\section{Findings Regarding the Correlation between Informal Relationships and Organizational Commitment}

Findings of the participants' views about the correlation between informal relationships in schools and organizational commitment are listed in Table 7.

Table 7. Correlation values between informal relationships in schools and organizational commitment

\begin{tabular}{llllll}
\hline & & $\begin{array}{l}\text { Organizational } \\
\text { Commitment }\end{array}$ & Adaptability & Identification & Internalization \\
\hline Informal & $\mathrm{r}$ & $.583^{* *}$ & $.252^{* *}$ & $.609^{* *}$ & $.449^{* *}$ \\
Relationships & $\mathrm{p}$ & .000 & .000 & .000 & .000 \\
\hline Intra & $\mathrm{r}$ & $.591^{* *}$ & $.305^{* *}$ & $.582^{* *}$ & $.449^{* *}$ \\
organizational & $\mathrm{p}$ & .000 & .000 & .000 & .000 \\
\hline Extra & $\mathrm{r}$ & $.379^{* *}$ & $.093^{*}$ & $.447^{* *}$ & $.300^{* *}$ \\
organizational & $\mathrm{p}$ & .000 & .046 & .000 & .000 \\
\hline
\end{tabular}

${ }^{*} \mathrm{p}<0.01{ }^{* *} \mathrm{p}<0.05$

As it is clear from Table 7, there was a "positive, moderate correlation" ( $r=0.583, \mathrm{p}<.05)$ between informal relationships in schools and organizational commitment. Accordingly, it might be suggested that the more informal relationships in schools exist, the more the organizational commitment increases. When the correlation between the factors is considered, it is seen that there is a positive, but slight correlation between intra and extra organizational informal relationships and organizational adaptability and there is a positive, moderate correlation between intra and extra organizational informal relationships and identification and internalization. It is also obvious that particularly the correlation between informal relationships and organizational commitment according to identification is ultimately moderate, very close to a strong correlation.

Predictive power of intra-and-extra organizational informal relationships on organizational commitment scores was examined with regression analysis and the results are shown in Table 8.

Table 8. Multiple regression analysis results on the prediction of organizational commitment by intra-and-extra organizational sub-dimensions of informal relationships

\begin{tabular}{llccccc}
\hline Model & $\begin{array}{l}\text { Predictive } \\
\text { Variables }\end{array}$ & $\mathbf{B}$ & $\begin{array}{l}\text { Standard } \\
\text { Error }\end{array}$ & Beta & $\mathbf{t}$ & $\mathbf{p}$ \\
\hline \multirow{2}{*}{$\begin{array}{l}\text { (Stepwise } \\
\text { method ) }\end{array}$} & $\begin{array}{l}\text { Intra- } \\
\text { organizational }\end{array}$ & 1.15 & .09 & $.53^{* *}$ & 12.51 & .00 \\
& Extra & & & & & .00 \\
& Organizational & .38 & .13 & $.122^{* *}$ & 2.89 & .00 \\
\hline
\end{tabular}

Dependent variable: Organizational commitment

$\mathrm{R}^{2}$ change $=.361 \quad{ }^{*} \mathrm{p}<.05,{ }^{* *} \mathrm{p}<.01$

In the multiple regression analysis, it was determined that after the sub-dimensions of informal relationships were added to the model (via stepwise), intra organizational $\left(\beta=.53^{* *}, \mathrm{p}<0.01\right)$ and extra organizational $(\beta=.12 * *, p<0.01)$ sub-dimensions of informal relationships predicted organizational commitment significantly. Each 1-unit increase of intra organizational and extra organizational informal relationship contributed a 1.15 unit and a .38 unit of increase in organizational commitment respectively. $34.9 \%$ 
of the total variance in organizational commitment is explained by intra organizational informal relationships $\left(\Delta \mathrm{R}^{2}=.349 ; \mathrm{p}<0.01\right)$ while $1.2 \%$ of the total variance is explained by extra organizational informal relationships $\left(\Delta \mathrm{R}^{2}=.012 ; \mathrm{p}<0.01\right)$. Therefore, $36.1 \%$ of the variance in organizational commitment is explained by these two sub-dimensions $\left(\Delta \mathrm{R}^{2}=.361 ; \mathrm{p}<0.01\right)$. As intra-and-extra organizational informal relationships increase, the organizational commitment of the teacher increases. The intra organizational sub-dimension has more predictive power than the extra organizational sub-dimension on organizational commitment.

\section{Discussion}

With its collectivist culture structure, Turkey has a network of social relationships in which social relationships and communication are experienced in a friendly, intimate, and face-to-face manner. Schools are organizations where these types of relationships experienced this social structure are reflected. These close informal relationships affect teachers' commitment to the school.

The research concluded that informal (natural, informal) relationships and interactions in schools were at a moderate level. According to the factors, it was found there were moderate intra organizational informal relationships between primary school staff, whereas extra organizational informal relationships were low. Accordingly, it might be suggested that the participant primary school administrators and teachers did not have high level intimate face to face relationships in schools and rarely met out of school. The employees barely spend time with or visit each other after school. This finding is parallel to some research findings (Akbaş, 2008; Çankaya, 2019; Doğan, 2017; Sabău ve Bibu, 2012; Şimşek, 2003), yet conflicts with some others (Deniz ve Uğurlu, 2016; Gürses, 2006; Şahin, 2007). Sabău and Bibu (2012) attribute the high level of informal relationship and communication to the prevalence of open door management approach in schools, and therefore to the ability of teachers to use formal communication channels easily.

However, going over the limits in intimate relationships between employees or between employees and administrators bears the risk of work abuse and chaos (Benkhoff, 1997). When informal relationships in organizations are uncontrollable, there might be resistance to change, which might be counted as a factor that hinders organizational development. For this reason, especially administrators need to keep formal and informal relationships balanced, turn to intimate, friendly relationships seasonably within proper limits and develop situational strategies for this matter (Katz and Kahn, 1977:357-359`; Mclurg, 1999).

In our study, it was determined that intra organizational informal relationships among school employees are at a moderate level. Accordingly, professional solidarity among employees at schools, intimate and warm relationships among employees and between administrators and employees, and bonds of friendship are at a moderate level. Weak informal relationships and dominant formal relationships can negatively affect the job satisfaction of the employees, teamwork, and voluntary participation in activities. The fact that informal relationships and intimacy are more intense than formal relationships may strengthen the sense of unity and team spirit among employees, On the other hand, when these relationships are exaggerated, they may cause a status quo that prevents organizational development and conflicts with formal organizational norms. This situation may hamper the job of the administrators as well as the control within the organization, and thus a chaotic climate dominated by chaos and unrest in the organization may occur.

It may be misleading to think that informal relationships and the norms developed as a result of these relationships are always negative and preventive for formal organizational relationships and goals. Although administrators have traditionally found informal relationships dangerous in terms of formal functioning and management norms, an effective management and leadership approach may turn this danger into a high efficiency and quality service for the organization. Administrators who provide such efficiency and quality can make a healthy transfer of authority and thus spend their time on more important and vital issues. However, this research has shown that even though administrators display an approach that supports the 
informal relationships of the employees and provide an appropriate environment, they cannot avoid reflecting the formal relationships in the eyes of teachers. This negativity can be eliminated by a set of informal activities in which administrators are more effective. For example, this can be turned into a tradition by giving a meal to the teachers at the end of the meetings held three times at the beginning of each academic year, at the beginning of the term, and at the end of the term.

It was found that relationships among employees outside of school are below the moderate level. Accordingly, it cannot be said that those working in schools meet much outside of working hours. According to the findings, it is important to find that employees rarely meet outside of school for activities such as spending time together outside of school, organizing home visits, and giving dinner invitations.

The research concluded that the participant primary school administrators and teachers felt "moderate" organizational commitment; they were greatly adaptable to schools according to the commitment factors, but moderately internalized their organizations and identified themselves with their organizations. Accordingly, organizational commitment felt by the participant primary school administrators and teachers was found high in adaptability, where personal benefits and rules were the main factors, rather than identification and internalization. This could be a negatively considered finding as adaptability shows superficial organizational commitment. This factor represents award winning or going unpunished rather than shared beliefs and obligatory formal togetherness of employees. Employees do what they do in organizations because they are obliged to, not because they would love to. Identification expresses employees' respect to organizational values, being proud of organizational membership, creating shared values and building a friendly working place atmosphere (Balcı, 2003, 28-29; Başaran, 2000, 233; Erdem, 2008; Polatcan ve Saylık, 2015).

Another striking finding in the study is that administrators and teachers have developed some informal relationships with each other, but they keep this limited to themselves, so they prefer to keep other family members such as spouse and children away from this interaction. In addition, it is observed that the participants prefer to come together in a more cultural and traditional social sharing such as condolences, weddings, and patient visits rather than coming together on religious and national holidays. This situation is also a reflection of the general form of social relations in Turkey.

The relationship between organizational commitment and individual characteristics has been the subject of many studies as in this study. For example, it was found that the commitment of the employee who spends many years in the organization is higher than the new ones. This result coincides with Benkhoff's (1997, 114) work.

Informal relationships between organizational staff bring some potential benefits for organizations. Intimate, friendly relationships in organizations are expected to strengthen team spirit and feelings of solidarity and collaboration between employees (Alotaibi, 2001; Özkalp and Kırel, 2011: 206-207). The research concluded that there was a positive, moderate correlation between informal relationships between school employees and organizational commitment. Accordingly, it might be suggested that the more informal relationships in schools exist, the more the organizational commitment increases at a moderate level. When the correlation between the factors is considered, it is seen that there is a slight correlation between intra and extra organizational informal relationships and organizational commitment according to adaptability, a moderate correlation between intra and extra organizational informal relationships and internalization, and finally, a very close to high correlation between intra and extra organizational informal relationships and identification. Thus, it could be concluded that informal relationships in organizations affect adopted and internalized organizational commitment more than adaptability, which reflects superficial organizational commitment of employees. In this context, it might be suggested that building well managed, proper, balanced informal (intimate) relationships in organizations will bring benefits for both organizations and employees. 
The fact that informal relationships significantly predict organizational commitment was yet another result obtained in the study. Accordingly, 34\% of the variance in organizational commitment is explained by intra-and-extra organizational informal relationships between teachers in schools. In other words, the increase in 1-unit informal relationship contributes to a .58-unit increase in organizational commitment. The intra organizational sub-dimension has more predictive power than the extra organizational sub-dimension on organizational commitment.

The modern society extends and enforces organizations in work life where there is a complicated work sharing system and hierarchical order. On the other hand, again contemporary organizations notice the importance of informal groups and gradually need informal (natural, intimate) relationships. As a matter of fact, today, human beings mostly need natural forms of relations based on love, friendship and fellowship more than ever. Therefore, people always tend to form groups where they may build intimate relationships and to develop pretty informal/intimate relationships in organizations, presumably because they have a natural tendency to do so. Informal relationships are getting more and more important since they meet some psycho-social needs such as togetherness and feelings of belonging. In this context, all employees in educational organizations should benefit from their natural communication skills beyond written formal rules. Such relationships create an organizational climate apt to solve organizational issues, increase organizational commitment and provide organizational effectiveness.

\section{Conclusion}

The following results were obtained in the study aiming to determine the opinions of teachers and administrators on the relationship between informal relationships and organizational commitment in primary schools. According to the participants:

- Schools have moderate and positive informal relationships.

- Informal relationships are not advanced outside of school and employees do not establish personal communication outside of work.

- There is a moderate level of organizational commitment in schools.

- Organizational commitment does not differ according to the size of the school and the title.

- As the term of employment (seniority) increases in schools, commitment also increases.

- Informal relationships are higher in schools with fewer students and teachers.

- Employees' commitment to the organization they work for is higher in terms of the adaptability dimension in which more importance is given to financial benefits and obligations rather than identification or internalization.

- There is a moderate and positive relationship between informal relationships and commitment.

- Intra-and-extra organizational informal relationships among teachers significantly predict their school commitment.

\section{Recommendations}

The following recommendations have been given in line with the results of the research:

- Informal relationships that serve the purposes of the formal organization should be supported and encouraged to ensure intra-organizational functionality.

- Activities including common social activities, dinner meetings, tea chats etc. within the school via administrators should be traditionalized. In this way, intra-organizational assessment meetings should be held 
at regular intervals. It should not be forgotten that this will contribute positively to the image of the organization.

- Administrators should delegate more power when it is ensured that informal relationships will help administration. It should not be forgotten that a healthy transfer of authority will ease the burden of the administration.

- It should not be forgotten that informal relationships and communication will provide additional communication channels to the organization.

- It should not be forgotten that administrators' shortcomings can be overcome by informal relationships.

- It should be taken into consideration that when informal relationships are not controlled, they can resist change and thus have a function that prevents organizational development.

- It should not be forgotten that informal relationships will serve employees with a team spirit and thus will be functional in providing satisfaction.

\section{Limitations}

This research is limited with the data collected with the assumption that 465 teachers working in public schools in Diyarbakır province gave sincere responses to the items in the scale form. This is a correlational study, thus, a longitudinal design may be more useful. 


\section{REFERENCES}

Akbaş, B. (2008). Örgütsel iletişimin örgütsel bağhllğg etkisi üzerine bir araştırma [A survey on the effect of organizational communication on organziational commitment] (Unpublished Master's Thesis). Afyonkarahisar: Afyon Kocatepe University, Institute of Social Sciences.

Allen, N. J., \& Meyer, J. P. (1990). The measurement and antecedents of affective, continuance and normative commitment to the organization. Journal of occupational psychology, 63(1), 1-18.

Alotarbı, A. G. (2001). Antecedents of organizational citizenship behavior: a study of public personnel in kuwait, Public Personnel Management, 30(3), 363-376

Aslan, C. (1997). Sosyoloji, kavramlar ve kullanımları [Sociology, terms and uses]. Adana: Baki Kitap Evi

Balay, R.(2000). Yönetici ve öğretmenlerde örgütsel bă̆lllı [Organizational commitment in school administrators and teachers]. Ankara: Nobel Publications

Balc1, A. (2003). Örgütsel sosyalleşme kuram, strateji ve taktikler [Organizational socialization theory, strategies and tactics], Ankara: PegemA Publications.

Balc1, A. (2013). Sosyal bilimlerde araştırma: Yöntem teknik ve ilkeler (10. Bask1), [Research in the social sciences: Methods, techniques and principles]. Ankara: PegemA Publications.

Başaran, İ, E. (2000). Örgütsel davranış [Organizational behavior]. Ankara: Umut Publications

Benkhoff, B. (1997). Ignoring commitment is costly: New approaches build the missing link between commitment and performance. Human Relations, 50(6), 701-726.

Bilgiç, A. S. (2006). Örgütsel iletişim ve bir uygulama [Organizational communication and an application] (Unpublished Master's Thesis). Malatya: İnönü University, Institute of Social Sciences.

Bolat, S. (1996). Eğitim örgütlerinde iletişim: H. Ü. Eğitim Fakültesi uygulaması [Communication in educational organizations: An application by Hacettepe University Faculty of Education]. Hacettepe University Faculty of Education Journal, 12(1), 75-80.

Budak, T. (2009). Illköğretim okullarında görev yapan kadrolu ve sözleşmeli öğretmenlerin örgütsel bağlllikları [Organizational commitment of permanent and contractual primary school teachers], (Unpublished Master's Thesis). Maltepe University, Institute of Social Sciences, İstanbul.

Can, H.(2006). Örgütsel davranış [Organizational behavior]. İstanbul: Arıkan Printinghouse

Celep, C. (1992). İlkokullarda yönetici öğretmen iletişimi [Communication between administrators and teachers in primary schools]. Hacettepe University Faculty of Education Journal, 8(1), 301-316.

Cooley, C. H. (1962) Social organization: A study of the larger mind. New York: Schocken. (Original work published 1909)

Çetin, M. (2004). Örgütsel vatandaşlık davranışı [Organizational citizenship behavior]. Ankara: Nobel Publications

Çubukçu, Z. \& Döndar, İ. (2003). Okul yöneticilerinin iletişim becerilerine ilişkin öğretmenlerin algı ve beklentileri [Teachers' Perceptions and Expectations about School Administrators' Communication Skills], Milli Eğitim Dergisi [MoNE Journal of Education], 157, 226-236.

Dönmezer, S. (1982). Sosyoloji [Sociology] (8th edition). Ankara Savaş Publications.

Durkheim, E. (1960). The division of labour in society. New York: Free Press. (Original work published 1893) 
Erdem, M. (2008). Öğretmenlere göre kamu ve özel liselerde iş yaşamı kalitesi ve örgütsel bağhllıkla ilişkisi [Correlation between working life quality in public and private high schools and organizational commitment in teachers' views], (Unpublished Doctoral Thesis). Ankara University, Institute of Educational Sciences.

Eserpek, A. (1981). Sosyoloji [Sociology]. Ankara: Dil, Tarih-Coğrafya Fakültesi Basımevi

Eren, E. (1989). Yönetim psikolojisi [Psychology of Management]. İ.Ü. İşletme Fakültesi Yayınları [İstanbul University Faculty of Business Management Publications]

Fichter, J. (2004). What is Sociology? (7th edition) (Trans. N. Çelebi). Ankara: Anı Publications.

Fraenkel, J. R., \& Wallen, N. E. (2003). How to design and evaluate research in education. McGraw-Hill Higher Education.

Geçimli, A. (2007). Örgütsel davranış biçimi olarak iletişim [Communication as a form of organizational behavior] (Unpublished Master's Thesis). Karaman: Selçuk University Institute of Social Sciences.

Gürses, Y. (2006). Eğitim örgütlerinde yöneticilerin etkili iletişim kurma becerilerinin belirlenmesine yönelik bir araştırma (Kütahya merkez ilçe örneği) [A survey on exploration of effective communication skills of administrators in educational organizations (a case study of Kütahya provincial district)] (Unpublished Master's Thesis). Kütahya: Dumlupınar University Institute of Social Sciences.

Hofstede, G. (1980). Culture's consequences: International differences in workrelated values, Beverly Hills, CA: Sage.

Hofstede, G., \& M. H. Bond (1984). Hofstede's culture dimensions: An independent validation using Rokeach's Value Survey. Journal of Cross-Cultural Psychology 15(4), 417-433.

Hofstede, G. (2001). Culture's consequences: Comparing values, behaviors, institutions and organizations across nations, 2.Edition. Sage.

Hoftede, G., Hofstede, G. J., \& Minkov, M. (2010). Cultures and organizations: software of the mind: Intercultural cooperation and its importance for survival. McGraw-Hill.

İmamoğlu, E. O. (1987). An interdependence model of human development. Ç. Kagıtçıbası (Ed.), Growth and progress in cross-cultural psychology, (p. 104-112). Lisse, Holland: Swets ve Zeitlinger.

Kağıtçıbaşı, Ç. (1984). Sex roles, value of children and fertility in Turkey. Ç. Kagitçibası (Ed.). Sex roles, family and community in Turkey, içinde (p. 151-180). Bloomington: Indiana University Press.

Karasar, N. (2009). Bilimsel araştırma yöntemleri (19th edition). Ankara: Nobel.

Katz, D. \& Kahn, R. L. (1977). Social Psychology of Organizations (Trans. H. Can, Y. Bayer). Ankara: Todai Publications.

Kilmen, S. (2015). Ĕ̆itim araştırmaları için SPSS uygulamal istatistik [SPSS applied statistics for educational research]. Ankara Edge Akademi

Kongar, E. (2002). Toplumsal değişme kuramları ve Türkiye gerçeği [Theories of social change and the reality of Turkey] (9 $9^{\text {th }}$ edition), İstanbul: Remzi Kitabevi.

Mcclurg, L. N. (1999). Organizational commitment in the temporary-help service industry, Journal of Applied Management Studies, 8(1), 5-26

Memduhoğlu, H. B \& Saylık, A. (2012). Okullarda informel ilişkiler ölçeğinin geliştirilmesi ve bazı değişkenler açısından incelenmesi [The development of the informal relations scale at schools and a survey in terms of some variations]. YYü, Ĕ̆itim Fakültesi Dergisi [Yüzüncü Yıl University Faculty of Education Journal], 9(1), 1-21 http://efdergi.yyu.edu.tr. 
Özan, M. B. (2006). Assessing primary school administrators' communication skills in teachers' and administrators' views. Educational Studies, 24, 153-160.

Özkalp, E. \& Kırel, Ç. (2011). Örgütsel davranış [Organizational behavior] (5 th edition). Bursa: Ekin Publications.

Polatcan, M., \& Saylık, A. (2015). The impact of the level of secondary education teachers' organizational socialization on organizational commitment. Mevlana International Journal of Education (MIJE), 5(2), 1330.

Randolph, K. A., \& Myers, L. L. (2013). Basic statistics in multivariate analysis. Oxford University Press.

Sabuncuoğlu, Z. (1984). Çalışma psikolojisi [Working psychology] (2nd edition). Bursa: Uludağ University Printinghouse.

Sargut, A. S. (2015). Kültürler arası farklılaşma ve yönetim [Cross-cultural differentiation and management]. İmge Kitabevi.

Saylık, A. (2017). Okul müdürlerinin paternalist liderlik davranışları ile Hofstede'nin kültür boyutları arasındaki ilişki [The relationship between school principals' paternalist leadership behavior and Hofstede's cultural dimensions], (Unpublished doctoral dissertation). Ankara Üniversitesi Eğitim Bilimleri Enstitüsü, Ankara.

Saylık, A., \& Aydın, İ. (2020) Development of the paternalist leadership behavior scale of school principals: Validity and reliability study. Ankara University Journal of Faculty of Educational Sciences (JFES), 53(1), 273-300. DOI: 10.30964/auebfd.631892

Şahin, A. (2007). Illköğretim okulu yöneticilerinin kişiler arası iletişim becerileri ve çatışma yönetimi stratejileri arasındaki ilişki [Correlation between Interpersonal communcation skills of primary school administrators and conflict management strategies] (Unpublished Master's Thesis). Antalya: Akdeniz University Institute of Social Sciences.

Şimşek, Y. (2003). Okul müdürlerinin iletişim becerileri ile okul kültürü arasındaki ilişki [Correlation between school administrators' communication skills and school culture] (Unpublished Doctoral Thesis). Eskişehir: Anadolu University Institute of Educational Sciences.

Tezcan, M. (1995). Sosyolojiye giriş; temel kavramlar [Introduction to sociology; Basic concepts] (4th edition). Ankara: Feryal Publications.

Tönnies, F. (1957). Community and society (Gemeinschaft und Gesellschaft). New Brunswick, NJ: Transaction

Türkkahraman, M. (2009). Teorik ve fonksiyonel açıdan toplumsal kurumlar ve kurumlar arası ilişkiler [Theoretical and functional relationships among social institutions and inter institutional relations]. Süleyman Demirel Üniversitesi İktisadi ve İdari İdari Bilimler Fakültesi Dergisi [Süleyman Demirel University Journal of Faculty of Economics and Administrative Sciences]. 14(2), 25-46.

Varol, M.(1993). Örgüt sosyolojisine giriş [Introduction to organizational sociology]. Ankara: Ankara University Faculty of Communication Publications No:2.

Yılmaz, A.S. (2007). Informel ilişki şekillerinin kurumsal yapılara yansımaları [Reflections of informal relation forms onto institutional structures], (Unpublished Doctoral Thesis). Firat University, Institute of Social Sciences, Elazı̆̆. 